\title{
Analysis of the Upgrade of China's Manufacturing Industry Structure from Outsourcing in Global Value Chain
}

\author{
Yu-Liu \\ Wuhan University of Technology, Wuhan, Hubei \\ 1377856175@qq.com
}

\begin{abstract}
Keywords: Global Value Chain, International division of labor, Outsourcing, Manufacturing Industry, Industrial structure
\end{abstract}

\begin{abstract}
With the deepening of economic globalization and the weakening of international trade barriers, the international division of labor begins to present a new model, from the initial division of labor between industries to the division of labor within the product - the Global Value Chain (GVC) division. China, as the largest developing country, many of its companies actively participate into this new model of division. However, due to the lack of core technologies and brands, China mainly lies in the labor-intensive parts through outsourcing. This paper first analyzes the outsourcing's contribution to the upgrade of Chinese manufacturing industry structure by upstreamness index. Then I build an econometric model to evaluate different factors attached to the upgrade of industrial structure. Finally, I put forward correlative suggestions to improve the status of international division of labor of China to achieve greater industrial structure upgrades.
\end{abstract}

\section{Introduction}

With the deepening of trade liberalization and the opening of the foreign investment environment, the pattern of international division of labor has achieved a rapid transformation from the division of labor among industries to division within the industry, then to division within products. The evolution and transformation of the international division of labor has led to a new production structure in the global production network -Global Value Chain (GVC). The GVC activity refers to the fact that its subject (usually a multinational company) based on comparative advantages around the world to seek target companies with the advantage of factor endowment to participate in production activities, with aims of achieving effective allocation of global resources and lowering production costs to obtain high profit. As a passive participant in GVC, Chinese manufacturing enterprises are mainly involved in outsourcing that is one part of the international division and work on some low-end and laborintensive manufacturing production activities such as production, processing, assembling and so on. Therefore, it's of great practical significance to study the difference of participating in GVC's lowend production activities makes to the upgrade of manufacturing industry structure.

Since the forming of the GVC, many scholars have studied the relationship between the outsourcing and the industrial structure and conducted their research as well as analysis on this issue. Liwei (2017) defined the theory of GVC explicitly and focused on analyzing the issue of industrial upgrading in developing countries in GVC. Anstràs, Fally et.al (2012) first proposed the concept of upstreamness. He Zuoyu and Daiqian (2016) linked the calculation of upstreamness with the GVC and analyzed China's status in international division of labor and its industrial structure. Zhang Weifu and Daixiang (2017) set up models to calculate the upstreamness of manufacturing industry and service industry, then they compared Chinese data with global mean and analyzed China's status and it's change in international division of labor. Lu Renxiang (2014) specifically studied the employment effect of China's participation in GVC. Wangqi (2016) came up with some detailed suggestion about promoting Chinese status in GVC.

This paper mainly studies the optimization effect of China's participation in outsourcing of GVC on manufacturing industry structure. First, pursuant to Zhang Weifu and Daixiang's data on the export upstreamness from 2000 to 2014, this paper specifically assays the change of China's manufacturing industry structure. Secondly, I set up an econometric model and individually introduce the factors 
affecting the manufacturing industry structure in this model. Finally, I draw relevant conclusions and adduce some suggestions to promote China's status in GVC and achieve greater industrial structure upgrades.

\section{Position of China's Manufacturing Industry in the International Division of Labor and Its Change}

\subsection{Analysis on the Current Situation of Chinese Manufacturing Industry in International Division of Labor}

Recently, the extent of China's manufacturing industry participation in global value chains has been deepening. Multinational corporations ${ }^{[1]}$ in developed countries distribute some production of incomparative advantage to developing countries through outsourcing and Foreign Direct Investment. Under this condition, Chinese export has increased quickly and has attracted lots of outsourcers and capital. Now, China is playing an important role in GVC.

China's manufacturing industry lies in the position of low value ${ }^{[2]}$ in GVC. On account of the abundant and cheap labor force and natural resources, China is implanted in the upstream with low increment of value in GVC by multinational corporations. However, developed countries, which rely on the advanced technology and abundant capital, occupy the production processes of high increment of value such as research and development, market, after-sales service and so on. Apart from that, there are still many problems to China when its manufacturing industry takes part in GVC. Multinational corporations depend on their monopolistic advantage to strengthen control over GVC and increase market share, which seriously prevents China's shift to production parts of high increment value. In itself, China is also confronted with some barriers such as shortage of talent, lack of capital and low technical level, which restrict its promotion of competitive power in $\mathrm{GVC}^{[3]}$. As a result, China is still at a disadvantage position in GVC system.

Although China's manufacturing industry is constrained by some technical and financial obstacles to the upstream of the GVC, its export volume and the advantage of international trade surplus have increased extensively due to the participation in GVC. Technical barriers have also bitten through the spillover effect from outsourcing activities. On this basis, the status of China's international division of labor has been substantially improved, which in turn has boosted the upgrade of the manufacturing industry structure.

\subsection{Methodology and data analysis}

Anstràs, Fally ${ }^{[4]}$ et.al first adduced the concept of upstreamness, which reflects the average distance of products in certain industry from the consumer terminal. The larger the upstreamness is, the further the distance is, the lower the status is in GVC, and the lower the technical level is. Industry upstreamness ${ }^{[5][6]}$ can objectively reflex the status of one industry under the division of GVC. Changes in industry upstreamness mirror changes in the status of individual industry. Different from industry upstreamness, export upstreamness stands on the national level and reflects the status of a certain economy such as manufacturing industry in GVC, which is systematic reflection. This paper focuses on the changes of manufacturing industry structure, so export upstreamness is regarded as the reference for its changes.

According to the formula was proposed by Anstràs, Fally et.al in the paper and utilizing the data in the World Input-Output Database (WIOD), the industry upstreamness for individual industry can be calculated. The computing method of export upsreamness is based on industrial calculation. Anstràs also used the industry upstreamness as variable to reckon the formula of export's. Zhang Weifu and Dai Xiang ${ }^{[6]}$ applied Anstràs' formula on export upstreamness and Johnson\&Noguera's method in export value-added to compute the upstreamness of China's manufacturing and service industry from 2000 to 2014, then they reckoned the mean in world and compared it with China. They also listed the corresponding rankings for China. This paper cites Zhang Weifu and Daixiang's computational data to observe the trend of the division of labor in China's manufacturing industry and explore the changes in its industrial structure. 
Table 1. China's manufacturing upstreamness of the export and its global ranking from 2000 to 2014

\begin{tabular}{ccc}
\hline Year & Manufacturing upstreamness of the export & Ranking \\
\hline 2000 & 3.85638 & 10 \\
2001 & 3.13123 & 9 \\
2002 & 4.02117 & 9 \\
2003 & 3.74748 & 8 \\
2004 & 4.01151 & 7 \\
2005 & 4.30332 & 7 \\
2006 & 4.35609 & 8 \\
2007 & 4.31367 & 7 \\
2008 & 4.43452 & 7 \\
2009 & 4.20928 & 8 \\
2010 & 4.41476 & 9 \\
2011 & 4.50807 & 10 \\
2012 & 4.44778 & 12 \\
2013 & 4.54744 & 13 \\
2014 & 4.50309 & 15 \\
\hline
\end{tabular}

Note: Zhang Weifu Daixiang. Has China's global value chain status improved? - Reassessment based on improved export upstreamness [J]. Journal of Zhongnan University of Economics and Law, 2017(4):90-99.

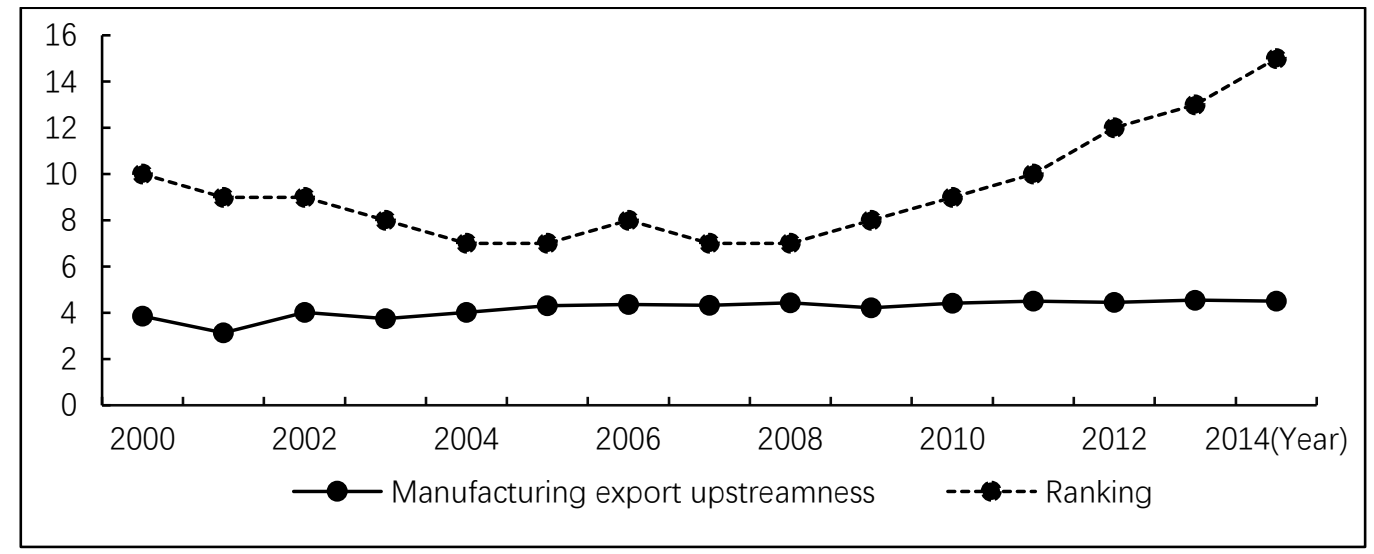

Fig.1. China's manufacturing export upstreamness and its global ranking from 2000 to 2014

The line chart, which is drawn based on the data of table 1, intuitively reflects manufacturing export upstreamness and its changes. From 2000 to 2014, export upstreamness of China's manufacturing industry mainly fluctuated around 4.0, with the lowest value in 2001. Judging from the trend of upstreamness, the manufacturing industry in China was stable from 2000 to 2014, which meant that China basically maintained the same distance from consumer terminal. Judging from the ranking and its trend, the ranking of China's manufacturing export upstreamness from 2000 to 2005 showed a gradual downward trend. Inversely, from 2007 to 2014, the ranking of China presented a steady upward with a quick rate of 53.3 percent.

The higher the economy ranks and the larger its export upstreamness values, the farther it is from the consumer terminal. That also implicates the upper its status is in GVC and the economy is engaged in less value-added production. Through a segmented analysis of China's manufacturing export upstreamness rankings, we can see that it was in the low-end of the GVC from 2000 to 2005 and it was gradually deteriorating. From 2007 to 2014, China's manufacturing industry was still at the lowend of the division of labor, but it presented a gradual improvement and a steady shift towards the high-end parts. Comprehensively speaking, the distance between China's manufacturing industry and consumers had been slowly shorten and its status in international division of labor had been gradually promoted in past years. China's manufacturing industry gently shifted from upstream of low increment of value to downstream of high increment of value. Its industrial structure was also promoted and optimized ${ }^{[7]}$. 


\section{Upgrade promotion effect on China's manufacturing industry structure by outsourcing activities in GVC}

As can be seen from the data and trends on export upstreamness, China's manufacturing industry position in the international division of labor is experiencing a rising stage. In views of the ranking data, we discover that China's manufacturing industry is active in the upstream production parts of the GVC and the position of the outsourcing country of the international outsourcing process. In recent years, as an important role in outsourcing activities, the rise of the status of China's manufacturing industry in the international division of labor and the optimization of its industrial structure are inseparable with the impact of outsourcing. The upgrade of the industrial structure brought by outsourcing activities mainly comes from the augment in capital stock from exports, the increase in employment ${ }^{[8]}$, and the spillover effect of technology ${ }^{[9][10]}$.

\subsection{Econometric model}

In this paper, $U_{t}$ is ranked as the dependent variable of China's ranking of manufacturing export upstreamness from 2004 to 2013. The total value of China's merchandise export trade, EXPt, China's employment of manufacturing industry, $\mathrm{LOBOR}_{t}$, and the technology index of China's manufacturing industry, $\mathrm{TECH}_{\mathrm{t}}$ calculated based on the total factor growth rate are independent variables. The linear regression model analyzes the relationship between independent variables and dependent variables.

$$
\ln \left(U_{t}\right)=C+\alpha \times \ln \left(E X P_{t}\right)+\beta \times \ln \left(L O B O R_{t}\right)+\gamma \times \ln \left(T E C H_{t}\right)+\varepsilon
$$

Here, $\mathrm{t}$ refers to the year, $\mathrm{t} \in[2004,2013]$. In this model, main concern is whether $\gamma$ is positive, because there is a clear positive correlation between the technology index $\mathrm{TECH}_{\mathrm{t}}$ and the ranking of upstreamness $U_{t}$. The greater the $\mathrm{TECH}_{t}$ is, the higher the technological level is, the more value creation China's manufacturing industry will achieve from participation in GVC and the closer it will be to consumers, the larger the $U_{t}$ will be. It is essential to note that although outsourcing has also greatly stimulated China's export that is processing trade and has brought about an increase in the capital stock and the funds used by China's manufacturing industry for research and development, there is huge difference in interests between contracting and outsourcing countries in outsourcing. The wide disparity may lead to a negative correlation between China's manufacturing upstreamness rankings and total export value.

\subsection{Description of independent variable data}

\subsubsection{Total value of merchandise export trade}

According to the statistics of UN COMTRADE, this paper intercepts the total amount of China's merchandise export trade between 2004 and 2013 from the annual release of trade data, for which manufacturing goods account a large proportion. The data are as follows:

Table 2. Total amount of China's merchandise export trade from 2004 to 2013

\begin{tabular}{cccc}
\hline Year & Export $($ million dollars) & Year & Export (million dollars) \\
\hline 2004 & 593326 & 2009 & 1201790 \\
2005 & 761953 & 2010 & 1578270 \\
2006 & 969380 & 2011 & 1899180 \\
2007 & 1217815 & 2012 & 2048940 \\
2008 & 1428860 & 2013 & 2210250 \\
\hline
\end{tabular}

Note: UN COMTRADE statistics of annual import and export of goods in the country

\subsubsection{Employment of manufacturing industry}

The involvement of China's manufacturing industry in the outsourcing in GVC is of great significance to the Chinese economy. The offshore shift of labor demand in outsourcing activities has greatly stimulated China's demand for labor and reduced the unemployment rate. According to the statistics of the National Bureau of Statistics, this paper selects the statistical data of the manufacturing industry between 2004 and 2013 from the employed persons in different industries, as detailed in Table 3 below: 
Table 3. China's Urban Employment of Manufacturing industry from 2004 to 2013

\begin{tabular}{cccc}
\hline Year & Employed population (ten thousand) & Year & Employed population (ten thousand) \\
\hline 2004 & 3050.8 & 2009 & 3491.9 \\
2005 & 3210.9 & 2010 & 3637.2 \\
2006 & 3351.6 & 2011 & 4088.3 \\
2007 & 3465.4 & 2012 & 4262.2 \\
2008 & 3434.3 & 2013 & 5257.9 \\
\hline
\end{tabular}

Note: China National Bureau of Statistics

\subsubsection{Manufacturing industry technology index}

The participation of China's manufacturing industry in the outsourcing of GVC has brought about technological upgrade to a certain extent. The demonstration effects and diffusion effects of technology from outsourcing have further promoted the technology of China's manufacturing industry. Total factor productivity(TFP) is used to measure the increase in the productivity of purely technological advances other than all tangible factors of production. The study of total factor productivity of manufacturing industry is the key to studying its technological progress. Zhang Yanqiu adopted the measurement of the TFP to study the technological progress of the manufacturing industry ${ }^{[11]}$. The specific data for her estimation is shown in Table 4 , in which the total factor productivity in the table is compared with the previous year.

Table 4. Total factor productivity of China's manufacturing from 2004 to 2013

\begin{tabular}{cccc}
\hline Year & TFP & Year & TFP \\
\hline 2004 & $1.299 \%$ & 2009 & $1.042 \%$ \\
2005 & $1.123 \%$ & 2010 & $1.060 \%$ \\
2006 & $1.114 \%$ & 2011 & $1.097 \%$ \\
2007 & $1.140 \%$ & 2012 & $1.023 \%$ \\
2008 & $0.958 \%$ & 2013 & $1.002 \%$ \\
\hline
\end{tabular}

Note: Zhang Yanqiu's Measurement Based on the Malmqusit Index Method of DEA and Panel Data of Manufacturing Subdivision Industry

Total factor productivity reflects the ratio of technological progress. To obtain indicators that reflect the technical level from 2004 to 2013, this paper assumes that the 2003 technical index is 1 and uses the following formula to calculate.

$$
\mathrm{TECH}_{t}=T E C H_{t-1} \times\left(1+T F P_{t}\right)
$$

Thereinto, $\mathrm{t}$ refers to the year, $\mathrm{t} \in[2004,2013] . \mathrm{TECH}_{\mathrm{t}}$ reflects to the technical index of $\mathrm{t}$ year, $\mathrm{TECH}_{2003}=1, \mathrm{TFP}_{\mathrm{t}}$ refers to the Total factor productivity of $\mathrm{t}$ year. The calculation results are shown in Table 5.

Table 5. Technical index of China's manufacturing industry from 2004 to 2013

\begin{tabular}{llll}
\hline Year & Technical index & Year & Technical index \\
\hline 2004 & 1.013 & 2009 & 1.068 \\
2005 & 1.024 & 2010 & 1.079 \\
2006 & 1.035 & 2011 & 1.091 \\
2007 & 1.047 & 2012 & 1.102 \\
2008 & 1.057 & 2013 & 1.113 \\
\hline
\end{tabular}

Note: Calculation results according to the data in Table 4

\subsection{Analysis of regression results}

\subsubsection{Fundamental Analysis}

This paper uses the Eviews and regression results as the Table 6 shows. On the whole, first, the $\mathrm{R}^{2}$ in the regression result is 0.916682 , which is very close to 1 . Second, the F-test value is 22.04946 , which is relatively large. Finally, the $\mathrm{P}$ value is 0.001225 , which is much less than 0.05 . Combination of the three indices indicates that the model is very significant. In terms of coefficients, the coefficient $\gamma$ before $\ln \mathrm{TECH}_{\mathrm{t}}$ is 7.513182 , which is consistent with our previous analysis. It shows that the higher the level of technology is, the more downstream the China's manufacturing industry is in division of 
labor of the GVC. The coefficient before $\operatorname{lnLOBOR}_{t}$ is 0.938353 , which indicates that it is in proportion to $\ln U_{t}$. That is, the outsourcing stimulates the demand for labor force in China's manufacturing industry, lowers the unemployment rate, promotes the development of China's economy and improves the efficiency of enterprises. Finally, it promotes the optimization of industrial structure. The coefficient before $\operatorname{lnEXP}_{t}$ is -0.403327 , which differs from $\operatorname{lnEXP} \mathrm{t}_{\mathrm{t}}$ and $\operatorname{lnLOBOR} \mathrm{t}$. It is in inverse proportion to $\ln U_{t}$, which is in line with the assumption that the interests between the contracting and outsourcing countries differ greatly. It illustrates that although China's export volume through the outsourcing is growing at a large rate and profits are increasing, it still has a big gap with some developed countries such as the United States.

Table 6. Econometric analysis results

\begin{tabular}{lllll}
\hline $\begin{array}{l}\text { Dependent Variable: LNUT } \\
\text { Method: Least Squares }\end{array}$ & & & \\
Date: 03/05/18 Time: 19:49 & & & \\
Sample: 2004 2013 & & & \\
Included observations: 10 & & & & \\
\hline \hline Variable & Coefficient & Std. Error & t-Statistic & Prob. \\
\hline \hline C & -0.336198 & 5.257888 & -0.063942 & 0.9511 \\
LNEXPT & -0.403327 & 0.262670 & -1.535488 & 0.1756 \\
LNLOBORT & 0.938353 & 0.424010 & 2.213044 & 0.0689 \\
LNTECHT & 7.513182 & 4.372197 & 1.718400 & 0.1365 \\
\hline \hline & 0.916682 & Mean dependent var & 2.149219 \\
R-squared & 0.875023 & S.D. dependent var & 0.232479 \\
Adjusted R-squared & 0.082186 & Akaike info criterion & -1.870485 \\
S.E. of regression & 0.040527 & Schwarz criterion & -1.749451 \\
Sum squared resid & 13.35242 & Hannan-Quinn criter. & -2.003259 \\
Log likelihood & 22.00446 & Durbin-Watson stat & 2.163099 \\
F-statistic & 0.001225 & & & \\
Prob(F-statistic) & & & \\
\hline \hline
\end{tabular}

Note: Results of regression.

\subsubsection{Specific analysis}

The leap-forward development of total export driven by outsourcing has brought abundant capital to China. The upsurge in capital stock has optimized China's industrial structure in two aspects. On the one hand, the increase in capital stock will, to a certain extent, hike the level of social income and the purchasing power of consumers, then optimize the consumption structure closely related with industrial structure. On the other hand, the escalation in capital stock will, to a certain extent, raise the flow of funds used for R\&D, which can not only enhance China's technological level and the status of international division of labor, but also optimize the industrial structure.

The rise in level of employment through outsourcing is mainly reflected in the increase in the number of jobs and the quality of employees. The burgeoning employment rate comes from the stimulating demand for labor in China's manufacturing contracting activities. The aggrandizement in employment quality comes from the high-quality and high-quantity requirements of the contracting countries (mainly developed countries) and the transmission to labor forces. The escalation in the number of laborers and the quality of the labor force move up production efficiency and production standards, then further promote the upgrade of industrial structure.

Technology spillover is embodied in China's imitation and learning from contracting countries. When contracting countries are confronted with problems that cannot be solved simply by improving the quality of employment, they will supervise and guide the production for outsourcing countries. When technicians of the contracting countries guide the outsourcing countries, they will have the risk of technology spillovers, which will bring opportunities for China to carry out technical learning. Technology as an important factor affecting the industrial structure, its promotion will contribute to the optimization of industrial structure. 


\section{Conclusions and suggestions}

\subsection{Conclusion}

The participation of China's manufacturing industry in the outsourcing of GVC has undoubtedly optimized industrial structure to a certain extent. Outsourcing has stimulated the demand of China's exports and labor force and has provided strong financial support for China's technological upgrading and innovation. Also, it has promoted the technological level and industrial structure. When confronting with the growth at trade surplus brought about by outsourcing of manufacturing industry, China cannot be blindly optimistic and confine the vision on the growth of profits any longer. Nowadays, China shifts its aim at striving to realize the complete transformation from an outsourcing country to a contracting country in manufacturing industry at an early stage and approaching to the downstream of high value creation in GVC. Therefore, it is more significant to focus on the gap of profits from outsourcing between China and developed countries and technological training.

\subsection{Suggestions for further upgrade of China's manufacturing industry structure}

\subsubsection{Improve the internal system of enterprises and fully prepare for technological innovation}

To achieve industrial upgrading in our country, we must first improve the endogenous capacity of enterprises $^{[12]}$, and gradually accomplish the upgrade towards high increment of value by increasing production efficiency and reducing costs based on the original parts in GVC. Only under the best production efficiency and perfect internal system of enterprises can enterprises fully prepare for technological upgrading and speed up footsteps to the downstream of GVC.

4.2.2 The government increase investment in $R \& D$ to accelerate the transformation from "made in China" to "created in China"

China's disadvantage position of being dominated in the GVC is mainly due to its lack of leading technologies. It is really crucial to develop advanced technologies to really get rid of the substratum status of the GVC. The Chinese government should vigorously support and encourage innovation funds and policies, which contribute to create a good environment for innovation both in the society and enterprises. Then China is supposed to make full preparations for its transition to the part of high increment of value in the GVC.

\section{References}

[1] Hanchong, Quyi. The threat of the division of Global Value Chains in China's Industrial Security [J]. Modern Management Science, 2015(5):42-44. (in Chinese)

[2] $\mathrm{Hu} \mathrm{H}, \mathrm{Gao}$ N. Discuss of Chinese industrial structure adjustment based on design innovation[C]// Design Management Symposium. IEEE, 2014:83-89.

[3] Yu Mingyuan, Fan Aijun. Global Value Chains, productive services, and the increased international competitiveness of China's manufacturing industry [J]. Collected Essays on Finance and economics (Journal of Zhejiang University of Finance and Economics), 2016, V208(6):1118. (in Chinese)

[4] Antràs $\mathrm{P}$, Chor D, Fally T, et al. Measuring the upstreamness of production and trade flows[J]. Cepr Discussion Papers, 2012, 102(3):412-416.

[5] Ju Jiandong, Yu Xinding. The role of China in the Global Value Chain - research based on China's industry upstreamness and customs data [J]. Nankai Economic Studies, 2014(3):39-52. (in Chinese)

[6] Zhang Weifu Daixiang. Has China's global value chain status improved? — Reassessment based on improved export upstreamness [J]. Journal of Zhongnan University of Economics and Law, 2017(4):90-99. (in Chinese)

[7] Zhang Tongbin, Wang Shuzhen, Bao Shuming. Contribution and decomposition research on 
"Made in China" to world economic growth [J]. The Journal of Quantitative \& Technical Economics, 2017(11):81-97. (in Chinese)

[8] Lu Renxiang. Analysis on the employment effect of Chinese enterprises participating in the division of Global Value Chain [J]. Commercial Times, 2014(21):42-44. (in Chinese)

[9] Yao Zhiyi. Global production networks and Chinese industrial structure upgrading[J]. International Conference on Energy and Environment,2011:420-422

[10] Wang Lei, Yao Hongxin. Global Value Chain embeddedness, knowledge spillovers, and clustered firms' innovation performance[J]. Journal of Donghua University (English Edition), 2014, 31(1):72-79. (in Chinese)

[11]Zhang Yanqiu. Study on technological progress of manufacturing Industry based on the index of technological progress [D]. Beijing University of Posts and Telecommunications, 2015. (in Chinese)

[12] Wangqi. Research on the upgrade of China's industrial structure under the Global Value Chain [J]. Modern SOE Research, 2016(16):145. (in Chinese) 